\title{
New Patterns of Spatial Distribution of the Population in Kainuu, Finland
}

\author{
ELLI HEIKKILÄ
}

Senior Researcher, Docent

Research Institute of Northern Finland

University of Oulu

Kajaani, Finland

\begin{abstract}
Migration is a process of long duration, which reflects the migrant's needs and values. The causes of migration relate to the physical and social environments, and these factors can be described by push and pull theories. The probability of moving to a specific location depends on the differential attractiveness of the various regions available to the migrant.

The rise of the turnaround phenomenon in migration in the developed countries has been explained by changes in the place-preference value system. Migration to the countryside has focused on areas within easy access of the main built-up areas in Kainuu, Finland.
\end{abstract}

Keywords: migration, turnaround migration, regional development, Finland

\section{Introduction}

Migration reflects both needs and values, but relatively little attention has been paid in migration research specifically to the analysis of values. Values have their own meaning even when potential migrants evaluate the alternatives between migration and non-migration. Migration itself is a process of a very long total duration, which proceeds from the evaluation of alternative destinations to the migration decision and ultimately to adaption to the environment, return migration or even to remigration. The causes of migration at the individual level relate to both physical and social environments (see Söderling 1983, 20-22). As a whole the personal desires and preferences of a potential migrant play an important role for the micro-level migration decisionmaking process (see Fischer et al. 1995, 23).

\section{Push and pull mechanisms of the areas}

The push and pull theories attempt to focus attention on the properties of the source and target areas for migration. There are factors about each area which either bind or attract people to it and factors which tend to repel people from it (Figure 1; Lee 1966, 47-57; Mangalam 1968, 9-10; Bogue 1969, 752-756). Migration may then be looked 
on as a situation involving choice, in which the decision as to whether to migrate or not is made by comparing the positive and negative aspects of the two areas. The concept of intervening obstacles comprises different kinds of restrictions on migration (for example travelling costs, demand for professional skill). There are differences among migrants in how these obstacles are overcome (see Lee 1966, 47-57; Lee 1969, 258295).

According to Bogue (1969, 752-754) migration is based on the individual's desire to satisfy his or her own needs and to avoid unpleasant experiences. Migration thus reflects a certain valid need which the individual cannot satisfy in the present living area. Mangalam (1968, 9-10) says that the background element for migration is relative deprivation. Deprivation can be seen when the individual feels dissatisfaction concerning the values he or she is trying to reach and there is a belief that these values can be better reached in new conditions.

Push and pull theories then set out to classify migrants according to which facts they tend to stress most when reaching their decisions. A move in which the subject has to make this decision principally on the basis of factors repelling him or her from the existing place of residence is said to represent forced migration and one in which the individual is primarily attracted towards the new place of residence represents target migration (see Huuhtanen 1975, 10). The meaning of values is pronounced in target migration, because migration is based on free decision (Seppänen 1986, 106-108).

The causes of migration are varied and complementary. Many studies have shown the links between migration and the labor market: the main motive for migrants is to find better economic conditions. The relative weight given to these aspects tends to be that long-distance moves, especially, are tied up with work and advancing one's career (Lewis 1982, 124-125). Return migrants also have an impact on the areas they move to. Their experiences and often material achievements can encourage young people to follow their example. This type of development can change a static community into a migration community. This process can be called "migration mentality" (Hoggart and Buller 1987, 190).

The motives of migration are dependent on the direction of migration. Migration from rural areas to the cities and towns, migration between rural communes, and migration between cities and towns are connected to the basic values of the society, in other words to making progress. There are other values when we think about migration from cities and towns to rural areas: people value rural areas as being more peaceful, more pleasant, and cleaner living environments and better places for bringing up chil-

Figure 1. Origin and destination factors and intervening obstacles in migration (Lewis 1982, 101).

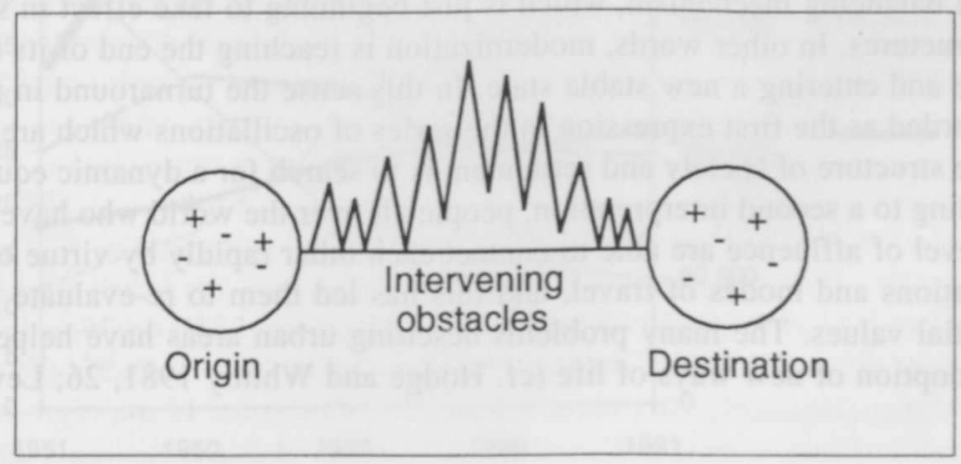


dren than urban areas (Seppänen 1986, 112).

In local migration within cities and also smaller areas, the direction often relates to stages in the life cycle. The basic idea behind sociopsychological models is that migration can be explained at the individual level in terms of the satisfaction of human needs. The various stages of family life and housing requirements, principally with respect to space and which exist at each stage, constitute an important mechanism explaining migration (Clarke 1972, 138; Lewis 1982, 89-93; Karjalainen 1986).

The hypothesis of the "value of immobility" has been presented. Immobility is a necessary prerequisite for any "investment" in the accumulation of location-specific assets and abilities which in turn allow for the exploitation of insider advantages. Insider advantages not only enable individuals to gain higher incomes, they also allow them to make better use of a given set of resources in order to maximize the quality of life. Gaining knowledge about location-specific economic, social and cultural opportunities, building up a social network or getting oneself involved in local affairs or political activities all requires a certain immobility and represent an "investment" that is lost if a decision is made to "go". Such insider advantages are non-transferable. A decision to "go" leads to their loss. Moreover, the basis for further investments in location-specific assets and abilities, for example the social network, is gone and the individual has to start from scratch in another location. The extent a micro-level decision maker is able to transfer her or his abilities and assets to a different macro-level unit should be an important determinant for the individual's propensity to migrate. The degree of skill transferability is related to the similarity of the origin and the destination, as well as the motive for migrating (Fischer et al. 1995, 28, 39-40).

\section{Turnaround as a changing mobility pattern}

Unanticipated changes in the character of internal migration in the developed countries have taken place in recent years (e.g. Fielding 1986, 224-225). One of the changes has been a replacement of urbanization by counterurbanization, despite the location in the major cities of favorable employment structures, higher-than-average wages and lower- than-average unemployment rates. When analyzing counterurbanization more closely, it can be seen that migration has been directed to an increasing extent towards rural environments in recent times, a type of migration that has proved universal in the developed countries and appears to have begun more or less simultaneously in different parts of the world (Naukkarinen 1983, 34). This trend of development corresponds to the expression "turnaround" used of the migratory flow itself (e.g. Pacione 1984, 136).

Various interpretations have been put forward in an attempt to explain such a movement (see Zelinsky 1983, 22; Naukkarinen 1983, 35). In the first place it can be seen as part of a balancing mechanism, which is just beginning to take effect in social and regional structures. In other words, modernization is reaching the end of its own transition stage and entering a new stable state. In this sense the turnaround in migration can be regarded as the first expression in the series of oscillations which are bound to occur if the structure of society and settlement is to search for a dynamic equilibrium.

According to a second interpretation, people all over the world who have achieved a certain level of affluence are able to contact each other rapidly by virtue of modern communications and modes of travel, and this has led them to re-evaluate their system of spatial values. The many problems besetting urban areas have helped to promote the adoption of new ways of life (cf. Hodge and Whitby 1981, 26; Lewis 1983, $150)$. 


\section{Features of migration to the rural areas in Finland}

Some features do emerge of increased migration towards rural environments in Finland. Net in-migration into the cities and towns reverted to net out-migration in 1977, when the urban areas as a whole began to lose population to the rural municipalities. The same trend has continued in the present decade, with migration directed outwards from the centers towards the urban margins, the central agglomerations of the neighboring rural municipalities, and also the country districts to some extent. At the same time migration between urban areas has increased markedly (Figure 2).

The Helsinki conurbation has been a concentration area of population within Finland. In fact one-fifth of all interprovincial migration in 1989 was directed towards this area. Helsinki itself received about one-half of this volume of migration. Closer analysis of the migration balance between Helsinki and the provinces of Finland in 1989 shows that this operated in favor of the former in all cases except for Uusimaa, the province in which Helsinki is situated. This is why Helsinki's migration balance was still a negative one ( -1531 persons) on account of its substantial losses to the other parts of the conurbation, notably the lower hierarchial cities of Vantaa and Espoo. Similar out-migration from Helsinki took place to other centers located lower in the hierarchy and a great distance away, including the peripheral areas of the province (Figure 3).

There have also been features of increasing movement to rural areas in Kainuu in 1980-85 (Karjalainen 1989). A doubling of migration from the main built-up areas

Fig u r e 2. Directions of internal migration in Finland in 1951-1991. (1) Migration from rural municipalities to urban municipalities, (2) from urban municipalities to rural municipalities, (3) from rural municipalities to rural municipalities, (4) from urban municipalities to urban municipalities, (5) total migration between municipalities in numbers.

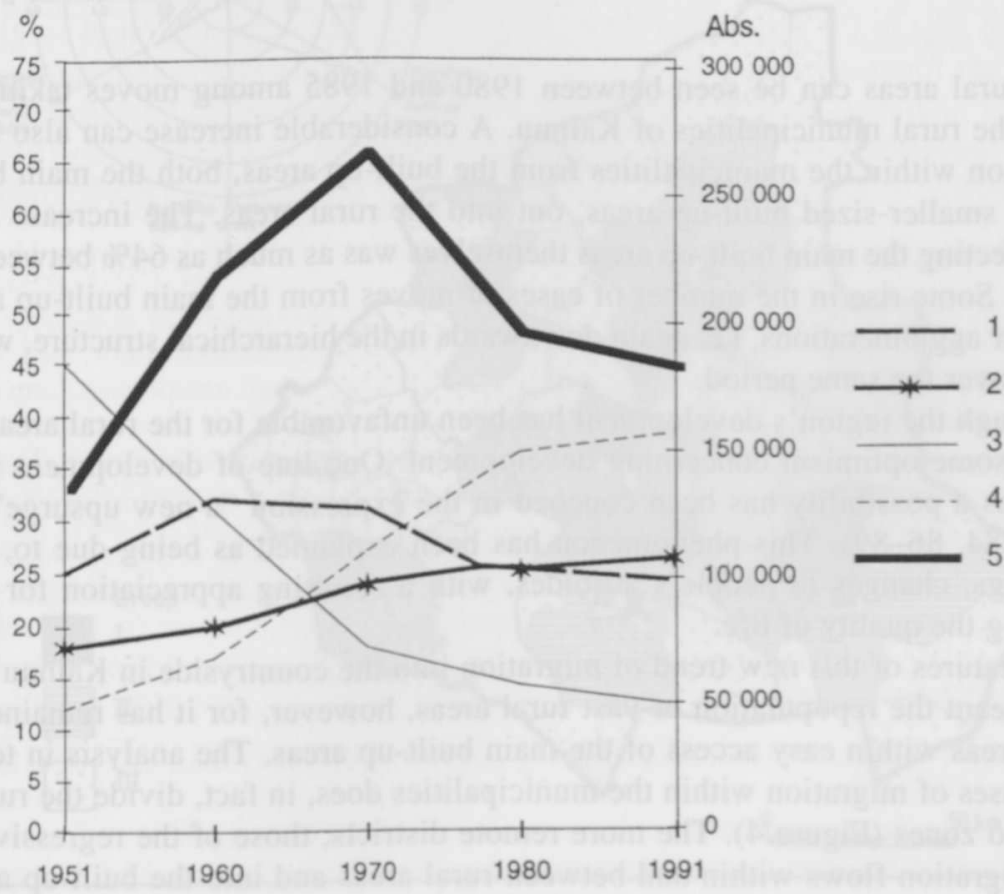


F i g u r e 3. Migration between Helsinki and the other municipalities in the province of Uusimaa (minimum 10 moves into or out of the municipality) and net migration of the municipalities in country-internal migration in 1989 (per 1,000 inhabitants). (a) capital center, (b, c) regional center, (d) city or area center.

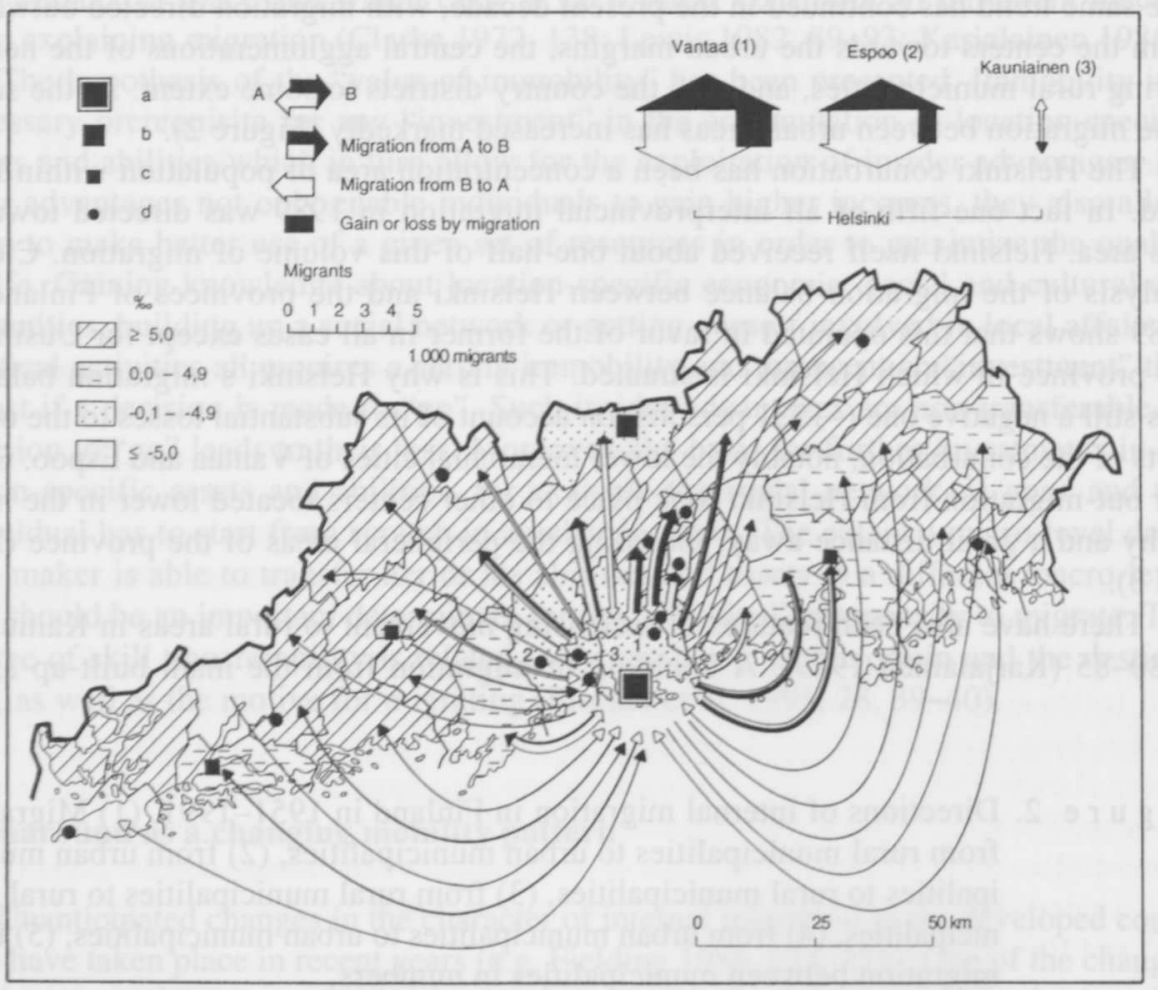

into the rural areas can be seen between 1980 and 1985 among moves taking place between the rural municipalities of Kainuu. A considerable increase can also be seen in migration within the municipalities from the built-up areas, both the main built-up areas and smaller-sized built-up areas, out into the rural areas. The increase in such moves affecting the main built-up areas themselves was as much as $64 \%$ between 1980 and 1985. Some rise in the number of cases of moves from the main built-up areas to the smaller agglomerations, i.e. again downwards in the hierarchical structure, was also observed over the same period.

Although the region's development has been unfavorable for the rural areas, there has been some optimism concerning development. One line of development in rural life seen as a possibility has been couched in the expression "a new upsurge" (Hautamäki 1984, 86-89). This phenomenon has been explained as being due to, among other things, changes in people's attitudes, with a resulting appreciation for factors enchancing the quality of life.

The features of this new trend of migration into the countryside in Kainuu county has not meant the repopulation of vast rural areas, however, for it has remained confined to areas within easy access of the main built-up areas. The analysis in terms of the processes of migration within the municipalities does, in fact, divide the rural areas into two zones (Figure 4). The more remote districts, those of the regressive type, feature migration flows within and between rural areas and into the built-up areas. It 
is in the rural areas located close to the main built-up areas, representing the intermediate group, that one finds a stronger flow of in-migration from the built-up areas, $27 \%$ compared with $12 \%$ in the regressive group. Even so this group still recorded a net population loss to the built-up areas. The built-up areas themselves, where the principal flows are internal ones, then form the developing areas. In these areas migration between the built-up areas took place principally in the direction of the smaller ones, whereas in the other groups it was directed towards the main built-up areas.

Centers have outgrown their administrative boundaries, because people have moved away from them to areas with easy access to centers. The same trend has been seen in migration between the town of Kajaani and the municipality of Sotkamo in Kainuu (Figure 5; Karjalainen 1991). The main built-up area of Sotkamo, the northwest rural areas, and the smaller-sized built-up area of Vuokatti have especially benefited from migration from Kajaani, which is the main center at the regional level in Kainuu. There are plans for a village community of one hundred inhabitants in Nuasjärvi (near the boundary between Kajaani and Sotkamo). The purpose of the plan is to create a wide and pleasant living area (Kainuun Sanomat 1991).

Fig u re 4. Grouping of the small-scale areas in the rural municipalities of Kainuu by municipality-internal migration processes, into developing areas (I), intermediate areas (II) and regressive areas (III).

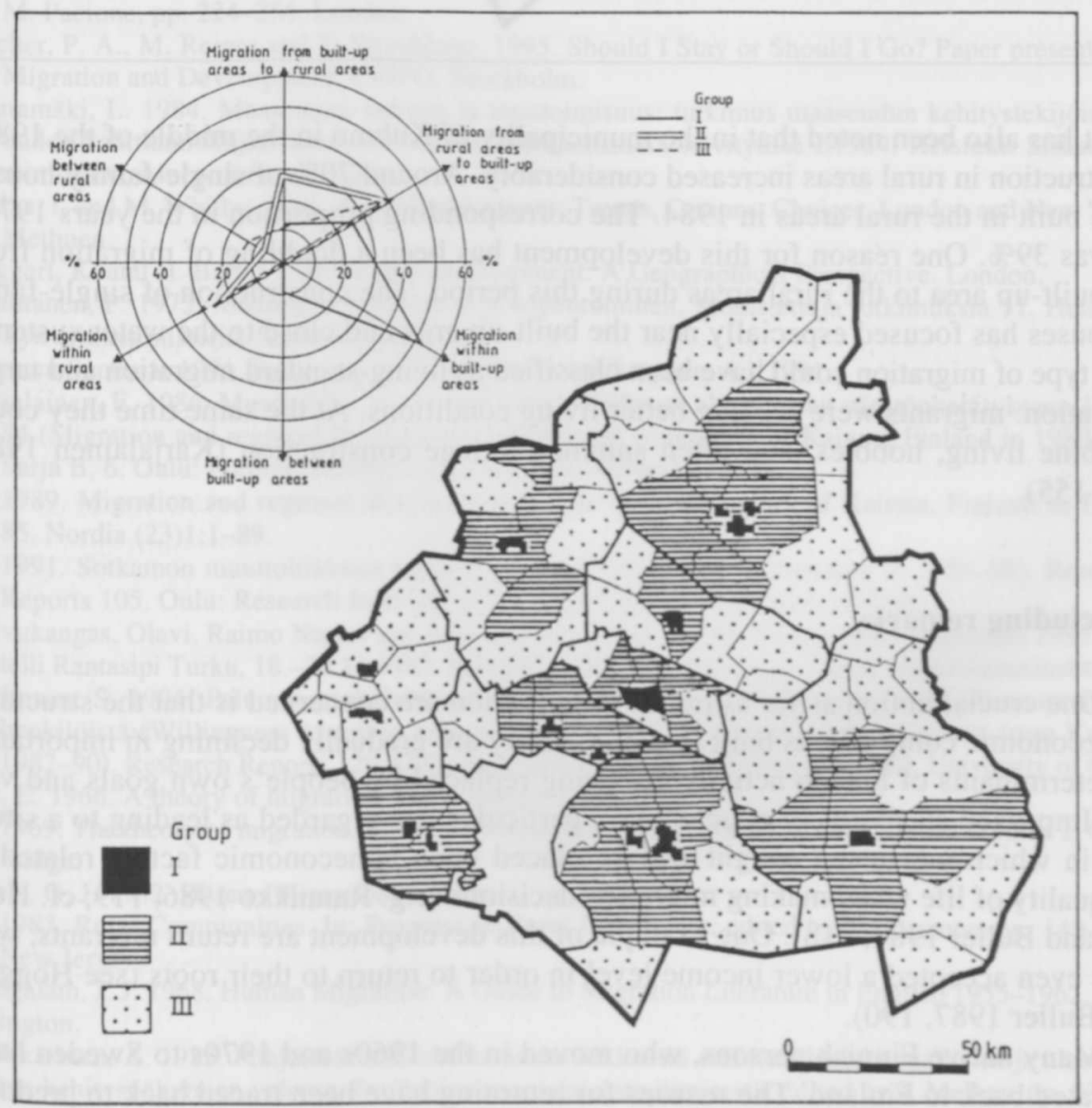


Fig u re 5. Migration from Kajaani to Sotkamo in 1986-88 by small-scale areas. (1) Municipality, (2) land register village, (3) built-up area.

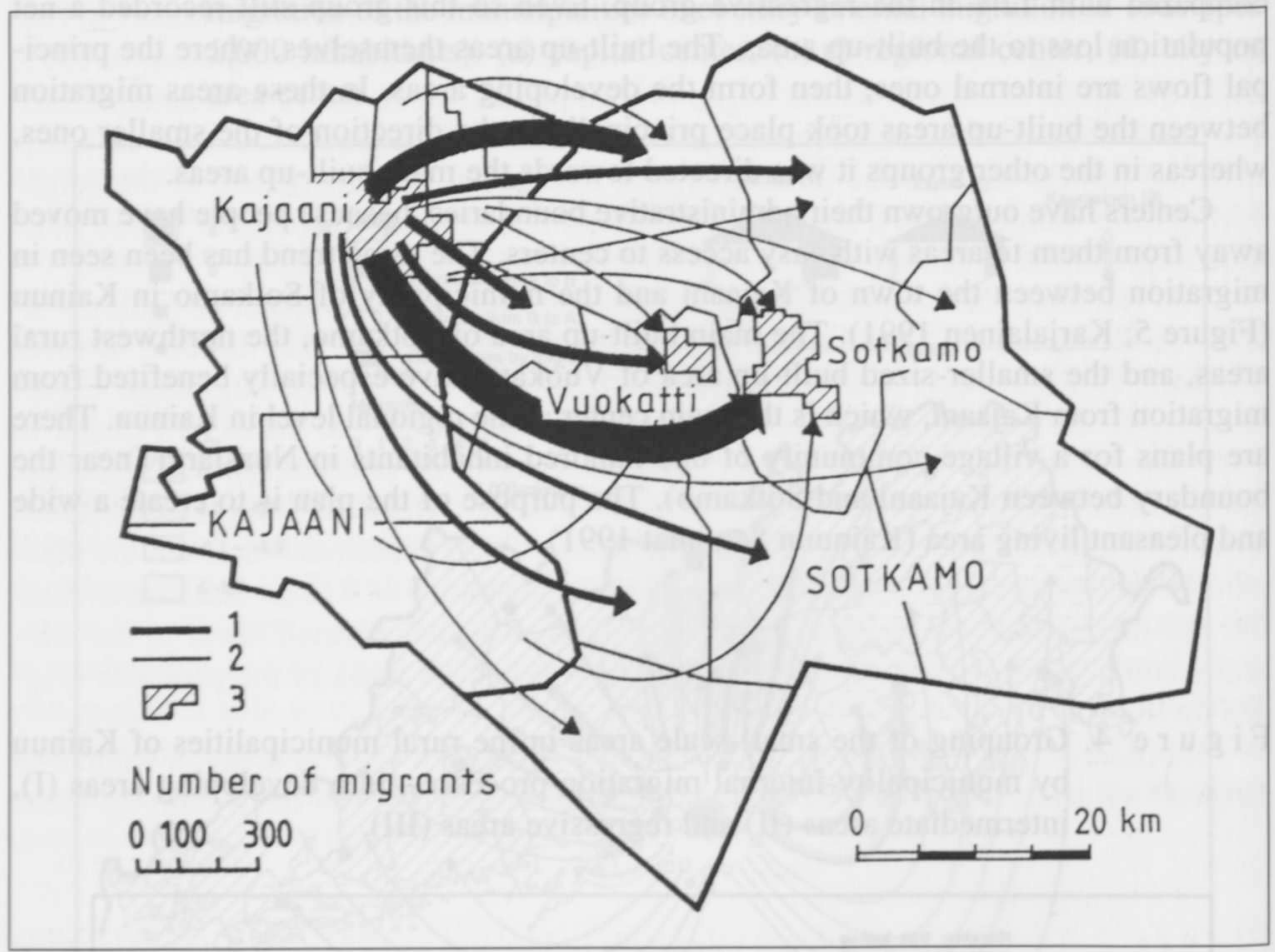

It has also been noted that in the municipality of Kuhmo in the middle of the 1980s construction in rural areas increased considerably. Around $70 \%$ of single-family houses were built in the rural areas in 1984. The corresponding proportion in the years 197982 was $39 \%$. One reason for this development has been a doubling of migration from the built-up area to the rural areas during this period. The construction of single-family houses has focused especially near the built-up area and close to the water systems. This type of migration could have been classified as living-standard migration and target migration: migrants were seeking better living conditions. At the same time they could combine living, hobbies, and often summer cottage construction (Karjalainen 1986, 153-155).

\section{Concluding remarks}

One crucial notion as far as trends in migration are concerned is that the structural and economic compulsions built into our society are gradually declining in importance as determinants of human activity are being replaced by people's own goals and values. Improved standards of education, in particular, are regarded as leading to a situation in which increasing weight will be placed upon noneconomic factors related to the quality of life when making migration decisions (e.g. Rannikko 1986, 119; cf. Hoggart and Buller 1987, 218). One example of this development are return migrants, who have even accepted a lower income level in order to return to their roots (see Hoggart and Buller 1987, 190).

Many native Finnish persons, who moved in the 1960 s and 1970 s to Sweden have migrated back to Finland. The reasons for returning have been traced back to predom- 
inantly non-economic considerations. Some surveys of return migration within Finland have shown that the most significant motives for returning are connected with housing and environmental factors, the second most common reason being employment, with considerable emphasis also on a desire to return to the area of one's birth (Karjalainen 1989, 41-43).

Going back to one's roots and to the countryside have also been apparent in Kainuu (Korhonen 1994, 46-47). Potential return migrants have been asked their reasons for returning and the main reason has been a longing for their roots. The group of other reasons forming the second most important category included Kainuu's nature and living surroundings, a summer cottage in Kainuu, the four seasons in Kainuu, relatives, hobbies, and better living conditions for their children. One question was included about interest in living in the different municipalities of Kainuu. An interesting result was that after Kajaani, the main center of the Kainuu county, was the municipality of Sotkamo. Sotkamo is very well-known for its nature and other soft values. In conclusion we can see that behind the answers of the potential return migrants are typical noneconomic factors and finally the values and needs of the individuals themselves.

\section{References}

Bogue, D. J. 1969. Principles of Demography. New York: John Wiley \& Sons.

Clarke, J. I. 1972. Population Geography. 2nd edition. Oxford: Pergamon Press.

Fielding, A. J. 1986. Counterurbanisation. In: Population Geography: Progress \& Prospect, edited by M. Pacione, pp. 224-256. London.

Fischer, P. A., M. Reiner and T. Straubhaar. 1995. Should I Stay or Should I Go? Paper presented in Migration and Development, CEIFO, Stockholm.

Hautamäki, L. 1984. Maaseudun kehitys ja omatoimisuus: tutkimus maaseudun kehitystekijöistä ja uuden kehittämislinjan hahmottumisesta. Aluepoliittisia selvityksiä I:1984. Helsinki: Sisäasiainministeriö, Aluepoliittinen osasto.

Hodge, I. and M. Whitby. 1981. Rural Employment: Trends, Options, Choices. London and New York: Methuen.

Hoggart, K. and H. Buller. 1987. Rural Development: A Geographical Perspective. London.

Huuhtanen, P. 1975. Muuttajan muotokuva ja sopeutuminen. Monistettuja tutkimuksia 11. Helsinki: Työvoimaministeriö, Suunnitteluosasto.

Kainuun Sanomat 1991. Sadan asukkaan rantakylä Jokikorpeen. 4.1.1991.

Karjalainen, E. 1986. Muuttoliike ja sen vaikutukset Kuhmon alueelliseen väestönkehitykseen 195984 (Migration and regional development in the rural communes of Kainuu, Finland in 1980-85). Sarja B, 6. Oulu: Pohjois-Suomen tutkimuslaitos, Oulun yliopisto.

- 1989. Migration and regional development in the rural communes of Kainuu, Finland in 198085. Nordia (23)1:1-89.

- 1991. Sotkamon muuttoliikkeen kehitys 1986-88 (Migration in Sotkamo in 1986-88). Research Reports 105. Oulu: Research Institute of Northern Finland, University of Oulu.

Koivukangas, Olavi, Raimo Narjus and Ismo Söderling (ed.). 1986. Muuttoliikesymposium 1985: Hotelli Rantasipi Turku, 18.-20.11.1985. Siirtolaisuustutkimuksia A 14. Turku: Siirtolaisuusinstituutti.

Korhonen, S. 1994. Paluumuuttohalukkuus Kainuuseen: tutkimus Kainuusta 1982-90 muuttaneista henkilöistä (Willingness to return migration to Kainuu: a research of the migrants from Kainuu 1982-90). Research Reports 120. Oulu: Research Institute of Northern Finland, University of Oulu.

Lee, E. 1966. A theory of migration. Demography 3(1):47-57.

-. 1969. The theory of migration. In: Migration, edited by J. A. Jackson, Sosiological Studies 2. Cambridge.

Lewis, G. J. 1982. Human Migration. London.

-. 1983. Rural Communities. In: Progress in Rural Geography, edited by M. Pacione, pp. 149-172. New Jersey.

Mangalam, J. J. 1968. Human Migration: A Guide to Migration Literature in English 1955-1962. Lexington.

Naukkarinen, A. 1983. Pohjoissuomalaisesta muuttoliikkeestä eräiden yhteiskunnallisten ja alueellisten kehitysnäkymien valossa. In: Pohjoissuomalaisesta ihmisestä, edited by J. Melkas, pp. 33-38. 
Oulun yliopisto, sarja C, 50. Oulu: Oulun yliopisto, Pohjois-Suomen tutkimuslaitos.

Pacione, M. 1984. Rural Geography. London: Harper \& Row.

Rannikko, P. 1986. Tietoyhteiskunnan muuttoliike: omien arvojen toteutumista vai taloudellisiin pakkoihin sopeutumista? In: Koivukangas, O. et al., pp. 119-130

Seppänen, P. 1986. Muuttoliike ja arvot. In: Koivukangas, O. et al., pp. 106-112.

Söderling, I. 1983. Maassamuutto ja muuttovirrat: vuosina 1977-78 kunnasta toiseen muuttaneiden elinolosuhdetutkimus. Siirtolaisuusinstituutti, Siirtolaisuustutkimuksia A 11. Turku: Siirtolaisuusinstituutti.

Zelinsky, W. 1983. The impasse in migration theory: a sketch map for potential escapees. In: Population Movements: Their Forms and Functions in Urbanization and Development, edited by P. A. Morrison, pp. 19-46. Liège: International Union for the Scientific Study of Population. 